\title{
Emotional Labor Strategies from Customer Point of View: A Systematic Literature Review
}

\author{
Amer Alsalhi* \\ PhD Student, Graduate School of Business, Universiti Kebangsaan Malaysia \\ Syed Shah Alam \\ Lecturer, Graduate School of Business, Universiti Kebangsaan Malaysia \\ Fazli Idris \\ Deputy Dean, Graduate School of Business, Universiti Kebangsaan Malaysia
}

\begin{abstract}
The behavior displayed by service employees affects customers' perception of service quality and their level of satisfaction. Therefore, understanding emotional labor strategies has become a key competitive advantage for service organizations. The purpose of this study is to provide an in-depth review studies that discussed and examined emotional labor strategies from customer point of view. This study used a systematic literature review approach on emotional labor studies. The results showed that customer satisfaction, customer loyalty and word of mouth are considered the most important outcomes of emotional labor strategies. Further, the results showed that the majority of previous studies used dyadic questionnaire as a data collection method. More importantly, drawn from the review results, a research framework was developed to show the customer outcomes of emotional labor strategies and the mediators/moderators between emotional labor strategies and customer outcomes. This article is one of the earliest studies that provides a systematic review of previous studies on emotional labor from customer point of view and uncovers the definitions, models, and methods and factors in order to clarify the emotional labor concept.
\end{abstract}

Keywords: Emotional labor, Surface acting, Deep acting, Customer satisfaction, Customer loyalty, Word of mouth, Systematic literature review, Research framework

DOI: $10.7176 / \mathrm{JMCR} / 57-03$

Publication date:June $30^{\text {th }} 2019$

\section{Introduction}

The concept of emotional labor (EL) was introduced by Hochschild (1979) and since then, researchers noticed the importance of this concept in service sector and how the emotional labor strategies could enhance the relationship between employees and customers (Lam \& Chen, 2012; Jung \& Yoon, 2014; Wong \& Wang, 2009; Zapf, 2002). Researchers started in paying more attention to emotional labor concept, which can be defined as a process of planning, controlling and displaying specific emotions that meet organizational goals (Karim \& Weisz, 2011). According to Chu and Murrmann (2006), EL aims to managing service employee's feelings and emotions and builds a strong relationship with customers, which promotes customer satisfaction with a specific product or service.

Expressed emotions from service employees could affect customer's impression, which in turn, affects the whole customer's perceptions of service quality of the organization (Lam \& Chen, 2012). Therefore, frontline employees should display certain emotions during service encounters with customers to meet organizational rules and to achieve customer satisfaction (Groth et al., 2009). According to Grandey et al., (2005), service organizations could get positive outcomes such as customer satisfaction and loyalty by applying EL strategies in an appropriate manner. Service organizations should concentrate more on emotions in work environment and they should enhance functional emotional laboring to create a better service environment, which will lead to increase service quality and customer satisfaction (Hwa \& Amin, 2016).

To date, most of EL studies had focused on the impact of these strategies on service employee health, burnout, satisfaction and performance (Hur et al., 2015). There are few studies that discussed and examined EL strategies from customer point of view such as (Chi \& Chin, 2018; Groth et al., 2009; Hur et al., 2015; Khan \& Awan, 2018; Lee et al., 2014; Tang et al., 2013; Van Dijk et al., 2011). Therefore, these gaps showed that a proper systematic literature review (SLR) to address the customer outcomes of EL strategies.

The purpose of this study is to conduct SLR on EL from customer point of view. Firstly, this article addresses the conceptualization of EL including EL definition and EL strategies. Secondly, presenting the outcomes of EL strategies adopted in prior studies between. Thirdly, presenting the mediators/moderators that have been used in our primary studies. Fourthly, discussing the data collection methods and the scales that prior studies used to examine EL strategies. The last part is proposing a research framework to illustrate the main variables that have been used in previous studies of emotional labor strategies from customer point of view. 
This paper is organized as follows:

1- Presenting the review method of studies on EL from customer point of view.

2- Reporting the SLR results and conducting a detailed discussion of the development of the research framework.

3- Discussing the implications of the SLR.

4- Concluding the SLR results and discussing opportunities for future work.

\section{Methodology}

This study follows the guidelines of Bandara et al., (2011) by employing a four-phase method to extract, codify, analyze and interpret the existing EL studies from customer point of view. These phases include articles extraction, pre-analysis, actual coding and the results. The following sub-sections clarify each stage. This study aims to answer the following questions:

1- What are the conceptualizations of EL concept and strategies?

2- What are the outcomes of EL strategies factors in the previous research?

3- What are the mediators/mediators that have been used in previous research?

4- What are the data collection methods and the EL scales that prior studies used to examine the relationship between EL and customer outcomes?

\subsection{Identification and Extraction of Studies}

The first phase was identifying and selecting the primary studies from several online databases that are used to cover a wide range of publications by following Webster and Watson (2002) recommendations of not limiting the search process to a specific set of journals. The duration of selected studies extends from 2009 to 2018. The databases used were Scopus and Science Direct. These databases are relevant and provide reliable studies. Further, this paper includes additional relevant articles by applying a manual recursive search. A thorough search of the grey literature (e.g. Google) was also undertaken.

The studies were extracted using keywords related to the research questions of this review such as: emotional labor and customer satisfaction, surface acting and customer satisfaction, deep acting and customer satisfaction, emotional labor and customer loyalty, surface acting and customer loyalty, deep acting and customer loyalty, emotional labor and word-of-mouth, etc. To ensure high level of accuracy and reliability of the results, the advanced search tool was applied. A total of 156 studies related to EL were identified. After removing the duplicated studies using Mendeley software, a total of 97 studies remained. Afterwards, inclusion/exclusion criteria were applied. Table 1 clarifies the inclusion and exclusion criteria were used in this study.

Table 1. Inclusion and exclusion criteria

\begin{tabular}{|l|l|}
\hline \multicolumn{1}{|c|}{ Inclusion Criteria } & \multicolumn{1}{c|}{ Exclusion Criteria } \\
\hline Published within selected period (2009-2018) & Not in the selected period \\
Published in Journals & Not in Journals \\
Study manuscript was written in English & Non English \\
EL from customer point of view & EL from service employees point of view \\
The respondents or part of respondents were customers & The respondents were service employees \\
Empirical studies & Non-empirical studies \\
\hline
\end{tabular}

After applying the inclusion and exclusion criteria, a total of (14) studies remained. Figure 1 clarifies the distribution of the studies through the years. As can be seen the graph, the publication of emotional labor from customer point of view context have increased from 2009 to 2013. The highest number of publication was recorded in 2013 with 3 studies. In 2015 and 2016 the number of studies published was 2 in each year. In 2016, only 1study was published. This distribution shows how the interest of customer behavior in e-commerce has increased by years. 
Figure 1. Publication timeline

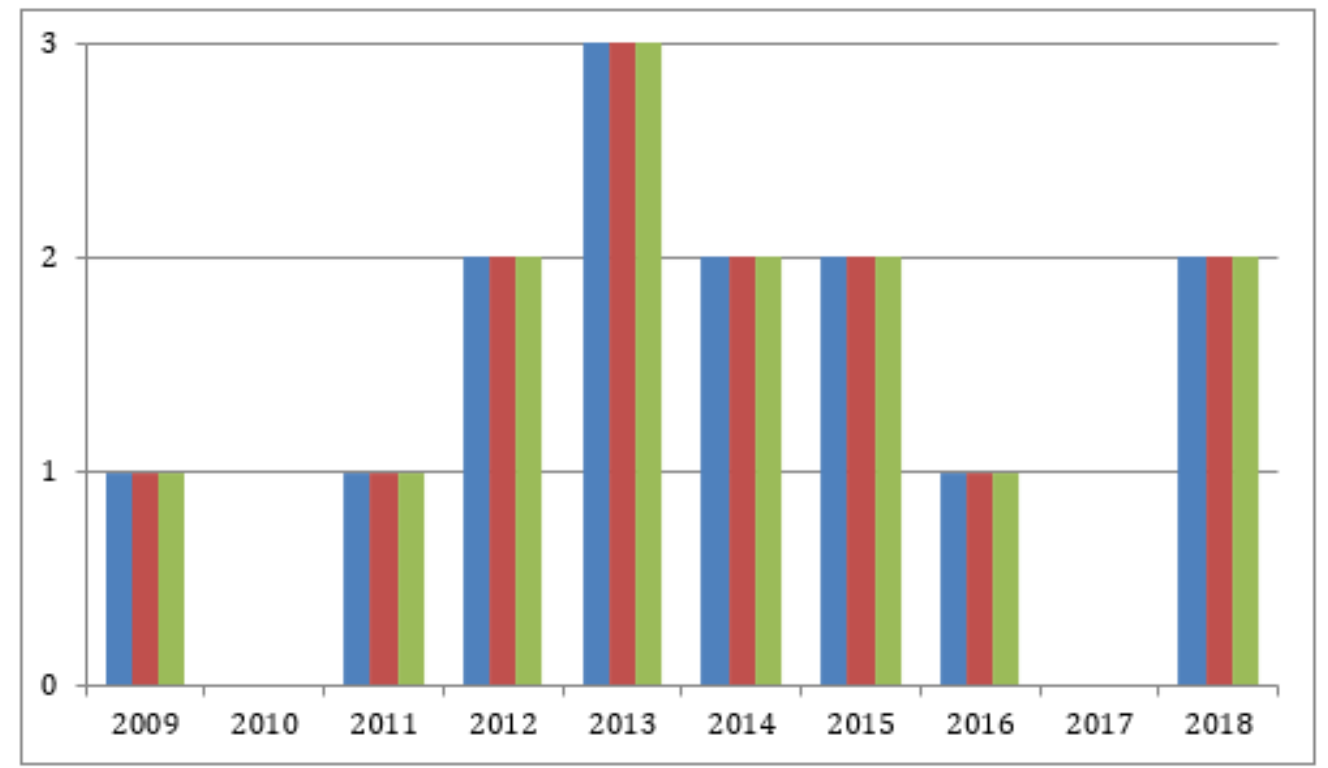

\subsection{Preparing for Analysis}

The pre-analysis phase consists of multiple steps. First, using Mendeley Desktop 1.19.2 in building a database references for all the primary studies. Second, converting all the primary studies to PDF files. After that, developing a file using Microsoft Word for each article to write all the information needed for the nodes. The suggested nodes were; EL conceptualization (EL definition and EL strategies), outcomes of EL strategies, mediators/mediators in previous models, and methodology used in previous research (Data collection method and EL scales). Finally, adding these files to Nvivo 12 in order to answer the SLR questions.

\subsection{Actual Coding and Write-Up}

As mentioned before, the first step was uploading all the Microsoft Word files on Nvivo 12. Then, creating a new file inside the list of files. After that, using two different layouts (the first one for the questions and the second one for the answers). Finally, applying the auto coding technique in order to design the nodes (EL conceptualization, EL outcomes, Mediators/Moderators, data collection methods and EL scales).

\section{Results}

This section presents detailed answers of the SLR questions for this review. The first section discusses how previous studies conceptualized the term El and presents the main definitions of EL strategies. The second section discusses the factors of EL including customer outcomes of EL and mediators/moderators that have been used in previous studies. The final section provides the data collection methods and the EL scales that the previous studies used to examine EL strategies.

\subsection{Conceptualizing Emotional Labor}

Hochschild (1983) is considered the first researcher who introduced emotional labor concept in her book The Managed Heart: Commercialization of Human Feeling. According to Khan and Awan (2018), the main idea of her book is that service organizations require their employees to sell their time and effort as well as regulate their emotions at work while dealing with customers in order to maximize the their profits.

Hochschild (1983) stated that emotional labor is the situation in which service employees have to regulate their emotions in order to meet organizational display rules. She clarified that emotional labor takes place only if three things occur as follows:

1) There is a face-to-face or aural contact between employee and other person or customer.

2) The employee produces an emotional response in other person or customer.

3) There is a control on all emotional activities of the employees from the employer.

In the same context, Grandey (2000) defined emotional labor as the process of managing both feelings and expressions to reach the organization's goal. Emotional labor became one of the most important topics in service industry, which led many researchers to define it such as (Goldberg \& Grandey, 2007; Grandey, 2000; Grove et al., 1998; Hochschild, 1983; Van Dijk et al., 2011). Based on the reviewed articles, we summarized all the definitions of EL that have been used in primary studies as shown in Table 2: 
Table 2. Emotional labor definitions

\begin{tabular}{|l|l|}
\hline \multicolumn{1}{|c|}{ EL Definition } & \multicolumn{1}{|c|}{ Originated from } \\
\hline $\begin{array}{l}\text { It's the situation in which service employees have to regulate their emotions in order } \\
\text { to meet organizational display rules. }\end{array}$ & (Hochschild, 1983) \\
\hline $\begin{array}{l}\text { The kind of impression management that helps an individual to direct his/her } \\
\text { behavior. }\end{array}$ & (Grove et al., 1998) \\
\hline $\begin{array}{l}\text { The process of regulating emotion by means of either antecedent-focused emotion } \\
\text { regulation or response-focused emotion regulation. }\end{array}$ & (Gross, 1998a; 1998b) \\
\hline $\begin{array}{l}\text { The process of managing both feelings and expressions of service employee to reach } \\
\text { the organization's goal. }\end{array}$ & (Grandey, 2000) \\
\hline $\begin{array}{l}\text { The management of emotional display by staff to satisfy organizational exceptions } \\
\text { during voice-to-voice of face-to-face interpersonal interactions. }\end{array}$ & (Van Dijk et al., 2007) \\
\hline
\end{tabular}

\subsubsection{Emotional Labor Strategies}

According to Hochschild (1983), emotional labor concept consists of two different strategies to manage and control service employee's emotions. Surface acting strategy defined as showing fake emotions to customers. On the other hand, deep acting strategy defined as making an effort to feel specific emotions according to conditions found in. After ten years of Hochschild's (1983) book, Ashforth and Humphrey (1993) suggested a third emotional labor strategy called genuine acting strategy. They argued that some emotions could be truly felt without any effort from service employees in displaying it to customers. The majority of researchers didn't accept the true feelings strategy except (Ashforth \& Humphrey, 1993; Diefendorff et al., 2005; Lee et al., 2014; Karim \& Weisz, 2011; Sharpe, 2005; Venkatesh \& Balaji, 2013; Yuhanis \& Zaiton, 2010). Therefore, this SLR concentrates only on surface acting (SA) and deep acting (DA) strategies. Based on the reviewed articles, we summarized all the definitions of (SA) and (DA) strategies that have been used in primary studies as shown in Table 3 and 4:

Table 3. Surface acting strategy definitions

\begin{tabular}{|l|l|}
\hline \multicolumn{1}{|c|}{ SA Definition } & \multicolumn{1}{|c|}{ Originated from } \\
\hline Faking emotions by displaying emotions not actually felt. & (Hochschild, 1983) \\
\hline Managing one's feeling as a result of observable expressions. & (Bitner, 1990; Bowen, 1990) \\
\hline The process of faking or outwardly assuming the desired emotions. & (Ashforth \& Humphrey, 1993) \\
\hline $\begin{array}{l}\text { The process of regulating the displayed emotions without changing the } \\
\text { inner feelings. }\end{array}$ & (Gross, 1998a) \\
\hline $\begin{array}{l}\text { Modifying the behaviors of service employees by suppressing or faking } \\
\text { expressions and displaying emotions not actually felt. }\end{array}$ & (Grandey, 2000) \\
\hline Putting on a mask without truly change the inner feeling and performance. & (Grandey, 2003) \\
\hline $\begin{array}{l}\text { The process of striving to customize the apparent gestures of actions } \\
\text { without altering the inner feelings. }\end{array}$ & (Zammuner \& Galli, 2005) \\
\hline $\begin{array}{l}\text { Manipulating outward appearances (facial expressions, gestures and voice } \\
\text { tone) in situations that demand an emotional display that is contrary to the } \\
\text { felt emotions. }\end{array}$ & (Chu \& Murmann, 2006) \\
\hline Amplifying emotions by displaying emotions not actually felt. & (Groth et al., 2009) \\
\hline
\end{tabular}

Table 4. Deep acting strategy definitions

\begin{tabular}{|l|l|}
\hline \multicolumn{1}{|c|}{ DA Definition } & \multicolumn{1}{|c|}{ Originated from } \\
\hline $\begin{array}{l}\text { It's an internal transformation and an active effort to feel more positively } \\
\text { during customer-service interactions. }\end{array}$ & (Hochschild, 1983) \\
\hline It's the management process of the actual feeling. & (Bitner, 1990; Bowen, 1990) \\
\hline The process of modifying inner feelings to meet the desired emotions. & (Ashforth \& Humphrey, 1993) \\
\hline $\begin{array}{l}\text { It's a strategy of modifying the behaviors of service employees through } \\
\text { internal change in order to display genuine emotions. }\end{array}$ & (Gross, 1998a) \\
\hline $\begin{array}{l}\text { Managing experienced emotions to be same as, or as close as possible to, } \\
\text { the required emotions of a certain situation. }\end{array}$ & (Grandey, 2003) \\
\hline $\begin{array}{l}\text { The process of striving to regulate the inner feelings to match the } \\
\text { expression of emotions that the service employee is obligated to show. }\end{array}$ & (Zammuner \& Galli, 2005) \\
\hline $\begin{array}{l}\text { It's a strategy of attempting to modify actual felt emotions so that a genuine } \\
\text { emotional display follows. }\end{array}$ & (Groth et al., 2009) \\
\hline
\end{tabular}

\subsection{Outcomes of Emotional Labor Strategies}

Through the SLR, we are further able to identify and provide a comprehensive picture of customer outcomes of 
emotional labor strategies. The majority of primary studies considered customer satisfaction, word of mouth and customer loyalty as the outcomes of emotional labor strategies. Customer satisfaction defined as customer's feeling of pleasure, which results from the comparison process between a product / service perceived performances and customer's expectations (Kotler \& Keller, 2009). Further, it represents how customers evaluate a product or service after consumption (Mittal \& Carly, 2010). From a total of 14 studies, 7 studies considered customer satisfaction/service satisfaction as one of customer outcomes of emotional labor strategies (Hur et al., 2015; Lee et al., 2014; Medler-Liraz \& Yagil, 2013; Wang \& Groth, 2014; Wu \& Shen, 2013; Wu \& Yuan, 2012; Yagil, 2012).

Regarding to word of mouth (WOM), it can be defined as a form of informal communication between two people or more about the ownership and characteristics of specific product or service (Chan \& Ngai, 2011; Taylor et al., 2012). Through the SLR, we noticed that 5 studies of our primary studies suggested word of mouth as one of customer outcomes of emotional labor strategies (Aziz et al., 2016; Chi \& Chen, 2018; Khan \& Awan, 2018; Lee et al., 2014; Van Dijk et al., 2011).

According to Akbar and Parvez (2009), customer loyalty represents customer attitude and commitment of repurchasing a specific product or service. Customer loyalty occurs when customers have a kind of preference to purchase a specific product or service consistently from a particular provider for a period of time (Lovelock \& Wirtz, 2011). We noticed that 4 studies from the 14 primary studies proposed customer loyalty as one of customer outcomes of emotional labor strategies (Groth et al., 2009; Khan \& Awan, 2018; Medler-Liraz \& Yagil, 2013; Yagil, 2012).

The primary studies of SLR proposed other outcomes as customer outcomes of emotional labor strategies such as service quality, customer-employee rapport and purchase decision. Table 5 summarizes the outcomes of emotional labor strategies that have been used in our primary studies as follows:

Table 5. Outcomes of emotional labor strategies

\begin{tabular}{|l|l|}
\hline \multicolumn{1}{|c|}{ EL Strategies Outcomes } & \multicolumn{1}{c|}{ Suggested by } \\
\hline Customer Satisfaction & $\begin{array}{l}\text { (Hur et al., 2015; Lee et al., 2014; Medler-Liraz \& } \\
\text { Yagil, 2013; Wang \& Groth, 2014; Wu \& Shen, } \\
\text { 2013; Wu \& Yuan, 2012; Yagil, 2012) }\end{array}$ \\
\hline Word of mouth (WOM) & $\begin{array}{l}\text { (Aziz et al., 2016; Chi \& Chen, 2018; Khan \& } \\
\text { Awan, 2018; Lee et al., 2014; Van Dijk et al., 2011) }\end{array}$ \\
\hline Customer Loyalty & $\begin{array}{l}\text { (Groth et al., 2009; Khan \& Awan, 2018; Medler- } \\
\text { Liraz \& Yagil, 2013; Yagil, 2012) }\end{array}$ \\
\hline Service Quality & (Medler-Liraz \& Seger-Guttman, 2015) \\
\hline Purchase Decision & (Tang et al., 2013) \\
\hline Positive Affect of Customers & (Wu \& Shen, 2013) \\
\hline Customer Employee-Rapport & (Wu \& Shen, 2013) \\
\hline $\begin{array}{l}\text { Long-term Customer Outcomes (The amount of customer } \\
\text { purchase, Service Relationship between Employee and } \\
\text { Customer and WOM) }\end{array}$ & (Chi \& Chen, 2018) \\
\hline $\begin{array}{l}\text { Visitor Outcomes (Elaboration, Attitude toward Nature } \\
\text { Conservation and Global Evaluation of Interpretation }\end{array}$ & (Van Dijk et al., 2011) \\
\hline
\end{tabular}

\subsection{Mediators/Moderators}

This section provides a comprehensive picture of all the mediators and mediators that previous studies used in EL literature from customer point of view.

Out of 14 studies, 7 studies used different mediators including (customer satisfaction, customer loyalty, hostile Behavior by service employee, job satisfaction, customer emotional experience, employee burnout and work engagement). Table 6 presents these mediators, clarifies the mediating relation and indicates to the study that used this mediator as follows: 
Table 6. Mediators

\begin{tabular}{|l|l|}
\hline \multicolumn{1}{|c|}{ Mediator Variable } & \multicolumn{1}{c|}{ Mable 6. Mediators } \\
\hline Customer Satisfaction & $\begin{array}{l}\text { Customer satisfaction mediates the relationship between emotional labor strategies } \\
\text { (Surface acting and deep acting) and Long-term customer outcomes (Chi \& Chen, } \\
\text { 2018) } \\
\text { Customer satisfaction mediates the relationship between deep acting strategy with } \\
\text { customer loyalty and word of mouth (Khan \& Awan, 2018) }\end{array}$ \\
\hline Customer Loyalty & $\begin{array}{l}\text { Customer loyalty mediates the relationship between perceived customer orientation } \\
\text { and word of mouth and also between perceived service quality and word of mouth } \\
\text { (Aziz et al., 2016) }\end{array}$ \\
\hline $\begin{array}{l}\text { Hostile Behavior by } \\
\text { Service Employee }\end{array}$ & $\begin{array}{l}\text { Hostile behavior mediates the relationship between emotional labor strategies } \\
\text { (Surface acting and deep acting) and service quality (Medler-Liraz \& Seger- } \\
\text { Guttmann, 2015) }\end{array}$ \\
\hline Job Satisfaction & $\begin{array}{l}\text { Job satisfaction mediates the relationship between emotional labor strategies (Surface } \\
\text { acting and deep acting) and customer satisfaction (Hur et al., 2015) }\end{array}$ \\
\hline $\begin{array}{l}\text { Customer Emotional } \\
\text { Experience }\end{array}$ & $\begin{array}{l}\text { Customer emotional experience mediates the relationship between emotional labor } \\
\text { strategies (Surface acting and deep acting) and purchase decision (Tang et al., 2013) }\end{array}$ \\
\hline Employee Burnout & $\begin{array}{l}\text { Employee burnout mediates the relationship between emotional labor strategies } \\
\text { (Surface acting and deep acting) with customer satisfaction and customer loyalty } \\
\text { (Yagil, 2012) }\end{array}$ \\
\hline Work Engagement & $\begin{array}{l}\text { Work engagement mediates the relationship between emotional labor strategies } \\
\text { (Surface acting and deep acting) with customer satisfaction and customer loyalty } \\
\text { (Yagil, 2012) }\end{array}$ \\
\hline
\end{tabular}

On the other hand, only 4 studies used moderator variables including (Relationship strength, service personalization, customer mood, customer deep acting detection accuracy, customer surface acting detection accuracy, service type and service sweet hearting). Table 7 presents these moderators, clarifies the moderating relation and indicates to the study that used this moderator as follows:

Table 7. Moderators

\begin{tabular}{|l|l|}
\hline Moderator Variable & \multicolumn{1}{|c|}{ Moderating Relation } \\
\hline Relationship Strength & $\begin{array}{l}\text { Relationship strength between service employee and customers moderates the } \\
\text { relationship between emotional labor strategies (Surface acting and deep acting) and } \\
\text { customer satisfaction (Chi \& Chen, 2018). } \\
\text { Relationship strength moderates the negative relationship among employee faked } \\
\text { positive emotions, employee suppressed negative emotions and customer satisfaction } \\
\text { (Wang \& Groth, 2014). }\end{array}$ \\
\hline Service Personalization & $\begin{array}{l}\text { Service personalization moderates the negative relationship among employee faked } \\
\text { positive emotions, employee suppressed negative emotions and customer satisfaction } \\
\text { (Wang \& Groth, 2014). }\end{array}$ \\
\hline Customer Mood & $\begin{array}{l}\text { Customer mood moderates the relationship between emotional labor strategies } \\
\text { (Surface acting and deep acting) and customer satisfaction, between customer } \\
\text { satisfaction and customer loyalty and also between customer satisfaction and word } \\
\text { of mouth (Khan \& Awan, 2018). }\end{array}$ \\
\hline $\begin{array}{l}\text { Customer Deep Acting } \\
\text { Detection Accuracy }\end{array}$ & $\begin{array}{l}\text { Customer deep acting detection accuracy moderates the relationship between deep } \\
\text { acting strategy and perceived customer orientation and also between deep acting } \\
\text { strategy and perceived service quality (Groth et al., 2009). }\end{array}$ \\
\hline $\begin{array}{l}\text { Customer } \\
\text { Acting } \\
\text { Accuracy }\end{array}$ & $\begin{array}{l}\text { Customer surface acting detection accuracy moderates the relationship between } \\
\text { surface acting strategy with perceived customer orientation and perceived service } \\
\text { quality (Groth et al., 2009). }\end{array}$ \\
\hline Service Type & $\begin{array}{l}\text { Service type moderates the relationship between surface acting strategy with } \\
\text { perceived customer orientation and perceived service quality (Groth et al., 2009) } \\
\text { Service type moderates the relationship between deep acting strategy with perceived } \\
\text { customer orientation and perceived service quality (Groth et al., 2009). }\end{array}$ \\
\hline Service Sweet Hearting & $\begin{array}{l}\text { Service sweet hearting moderates the relationship between emotional labor strategies } \\
\text { (Surface acting and deep acting) and customer satisfaction (Chi \& Chen, 2018). }\end{array}$ \\
\hline
\end{tabular}

\subsection{Data Collection Methods and EL scales}

This section presents the SLR results regarding data collection method that previous studies used to collect their data, the industries where the data collected and the scales that used to examine emotional labor strategies. 
Regarding to data collection method, we noticed from SLR that 10 studies out of 14 used dyadic questionnaire method (service employees and customers) in data collection process including (Chi \& Chen, 2018; Groth et al., 2009; Hur et al., 2015; Medler-Liraz \& Seger-Guttman, 2015; Medler-Liraz \& Yagil, 2013; Tang et al., 2013; Van Dijk et al., 2011; Wang \& Groth, 2014; Wu \& Yuan, 2012; Yagil, 2012). On the other hand, only 4 studies used self-administrated questionnaire including (Aziz et al., 2016; Khan \& Awan, 2018; Lee et al., 2014; Wu \& Shen, 2013).

Regarding to the industries where the data collected, SLR results revealed that the primary studies collected data from different industries such as airline industry, mobile phone shop sites, insurance companies and homecare firms. Further, SLR results showed that there are multiple scales have been used in the primary studies in order to examine emotional labor strategies as shown in Table 8:

Table 8. Methods and scales

\begin{tabular}{|c|c|c|c|}
\hline Primary Study & Data Collection Method & Industry & EL Scale \\
\hline (Aziz et al., 2016) & Questionnaire & $\begin{array}{l}\text { Airline industry in } \\
\text { Malaysia }\end{array}$ & $\begin{array}{l}\text { (Huang et al., 2011) } \\
\text { (Groth et al., 2009) } \\
\text { (Kim et al., 2012) }\end{array}$ \\
\hline (Chi \& Chen, 2018) & Dyadic questionnaire & $\begin{array}{l}\text { Insurance firm } \begin{array}{l}\text { and } \\
\text { various } \\
\text { occupations in China }\end{array} \\
\end{array}$ & $\begin{array}{l}\text { (Brotherdige \& Lee, } \\
\text { 2002) }\end{array}$ \\
\hline (Groth et al., 2009) & Dyadic questionnaire & $\begin{array}{ll}\text { Variety of } & \text { service } \\
\text { industries in UK } & \end{array}$ & $\begin{array}{l}\text { (Brotherdige \& Lee, } \\
\text { 2003) }\end{array}$ \\
\hline (Hur et al., 2015) & Dyadic questionnaire & $\begin{array}{l}\text { Home care firm in South } \\
\text { Korea }\end{array}$ & $\begin{array}{l}\text { (Diefendorff et al., } \\
2005)\end{array}$ \\
\hline (Khan \& Awan, 2018) & Questionnaire & $\begin{array}{l}\text { Bank customers in } \\
\text { Pakistan }\end{array}$ & $\begin{array}{l}\text { (Brotherdige \& Lee, } \\
\text { 2003) }\end{array}$ \\
\hline (Lee et al., 2014) & Questionnaire & $\begin{array}{l}\text { Travel Agenesis in } \\
\text { Malaysia }\end{array}$ & $\begin{array}{l}\text { (Diefendorff et al., } \\
\text { 2005) }\end{array}$ \\
\hline $\begin{array}{l}\text { (Medler-Liraz \& Yagil, } \\
\text { 2013) }\end{array}$ & Dyadic questionnaire & $\begin{array}{l}\text { Variety of service } \\
\text { industries in Israel }\end{array}$ & $\begin{array}{l}\text { (Brotherdige \& Lee, } \\
\text { 2002) }\end{array}$ \\
\hline $\begin{array}{l}\text { (Medler-Liraz \& Seger- } \\
\text { Guttmann, 2015) }\end{array}$ & Dyadic questionnaire & $\begin{array}{l}\text { Communication } \\
\text { company in Israel }\end{array}$ & $\begin{array}{l}\text { (Brotherdige \& Lee, } \\
\text { 2002) }\end{array}$ \\
\hline (Tang et al., 2013) & Dyadic questionnaire & $\begin{array}{l}\text { Mobile phone shop sites } \\
\text { in China }\end{array}$ & $\begin{array}{l}\text { (Brotherdige \& Lee, } \\
\text { 2003) }\end{array}$ \\
\hline (Van Dijk et al., 2011) & Dyadic questionnaire & Zoo in Australia & $\begin{array}{l}\text { (Brotherdige \& Lee, } \\
\text { 2003) }\end{array}$ \\
\hline (Wang \& Groth, 2014) & Dyadic questionnaire & $\begin{array}{l}\text { Variety of service } \\
\text { industries in UK }\end{array}$ & (Glomb \& Tews, 2004) \\
\hline (Wu \& Shen, 2013) & Questionnaire & Hotel in China & Not specified \\
\hline (Wu \& Yuan, 2012) & Dyadic questionnaire & Transportation in China & Not specified \\
\hline (Yagil, 2012) & Dyadic questionnaire & $\begin{array}{l}\text { Variety of service } \\
\text { industries in Israel }\end{array}$ & $\begin{array}{l}\text { (Brotherdige \& Lee, } \\
\text { 2003) }\end{array}$ \\
\hline
\end{tabular}

\section{The Proposed Conceptual Framework}

After reviewing the previous frameworks of all the primary studies, we noticed that the majority of studies examined emotional labor strategies from both point of views (service employees and customers). Out of 14 studies, there are only four studies that gave the full concentration on examining the effect of emotional labor strategies on customers without examining their effect on service employees (Aziz et al., 2016; Khan \& Awan, 2018; Lee et al., 2014; Wu \& Shen, 2013). Therefore, the proposed conceptual framework of this study concentrates only on emotional labor strategies from customer point of view. Also, SLR results revealed that only one study considered genuine acting strategy as one of emotional labor strategies and examined its relationship with customer outcomes (Lee et al., 2014). Therefore, the proposed conceptual framework of this study considers genuine acting strategy as one of emotional labor strategies.

The proposed conceptual framework of this study depends on two studies (Khan \& Awan, 2018; Lee et al., 2014). According to Khan et al. (2018) framework, the independent variables are surface acting strategy and deep acting strategy. They are hypothesized to have direct relationship with customer satisfaction and indirect relationship with customer loyalty and word of mouth. Meanwhile, customer satisfaction is hypothesized to mediate the linkage between independent variables with customer loyalty and word of mouth. Customer mood is hypothesized to moderate the linkage between emotional labor strategies and customer satisfaction and also between customer satisfaction and dependent variables (customer loyalty and word of mouth). Dependent variables 
are labeled as customer loyalty and word of mouth. On the other hand, Lee et al. (2014) framework consists of three independent variables (Surface acting strategy, deep acting strategy and genuine acting strategy), while dependent variables are labeled as customer satisfaction and word of mouth.

The independent variables of the proposed conceptual framework of this study are surface acting strategy, deep acting strategy and genuine acting strategy. Meanwhile, customer satisfaction is hypothesized to mediate the linkage between independent variables with customer loyalty and word of mouth. Customer mood is hypothesized to moderate the linkage between independent variables with customer satisfaction. Also it proposes to moderate the relationship between customer satisfaction and dependent variables (customer loyalty and word of mouth). Dependent variables are labeled as customer loyalty and word of mouth as shown in Figure 2:

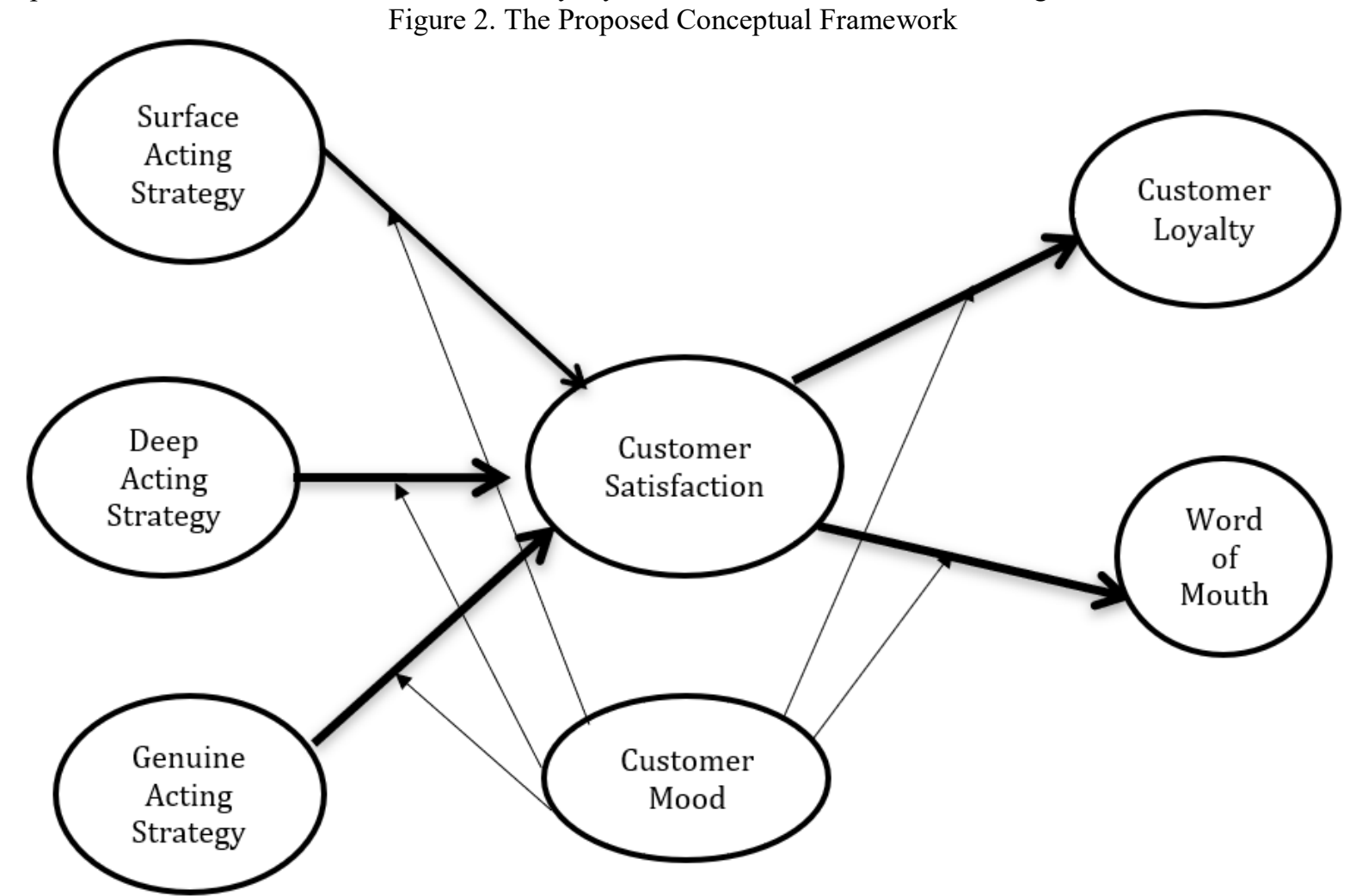

\section{Discussion and Implications}

The purpose of this study is to conduct a systematic literature review on emotional labor from customer point of view. This article focuses on empirical research studies that examined customer outcomes of emotional labor strategies. A total of 14 studies were identified through our systematic review from prominent academic databases. More importantly, this paper proposes a research framework to expose the mediators/moderators and outcomes of emotional labor strategies from customer point of view.

This study is one of the earliest studies that present the outcomes of emotional labor strategies and mediators/mediators that have been used in previous studies. The results showed that customer satisfaction, customer loyalty and word of mouth are considered the most important outcomes of emotional labor strategies. In addition, the results proved that customer satisfaction is considered as a mediator between emotional labor strategies with customer loyalty and word of mouth (Chi \& Chen, 2018; Khan \& Awan, 2018). On the other hand, the results showed that customer mood partially moderates the relationship between emotional labor strategies with customer satisfaction and also between customer satisfaction with customer loyalty and word of mouth (Khan \& Awan, 2018).

This study revealed that previous studies on emotional labor strategies from customer point of view used both methods self-administrated questionnaire and dyadic questionnaire for data collection process. Further, it reveals that the majority of previous studies used the emotional labor scale that developed by Brotherdige and Lee (2003) to examine emotional labor strategies.

\section{Conclusion}

This study provides a systematic review of emotional labor from customer point of view. The current study derives insights based on the discussion of emotional labor conceptualization, outcomes, mediators, moderators, data 
collection methods and scales. This effort will contribute in enhancing the level of understanding emotional labor concept and it will be valuable for both academics and practitioners. The results of this study will enhance marketing research by providing a theoretical basis for developing empirical research on EL and it paves the way for future studies on EL from customer point of view.

\section{References}

Akbar, M.M., \& Parvez, N. (2009). Impact of service quality, trust, and customer satisfaction on customer loyalty. ABAC Journal, 29(1), 24-38.

Ashforth, B.E., \& Humphrey, R.H. (1993). Emotional labor in service roles: the influence of identity. The Academy of Management Review, 18, 88-115.

Aziz, N. A., Najafi, B., Al-Shuaibi, A. S. I., \& Shamsudin, F. M. (2016). Behavioural consequences of customer perception on emotional labor among airline service employees. International Review of Management and Marketing, 6 (7 Special Issue), 162-168.

Bandara, W., Miskon, S., \& Fielt, E. (2011). A systematic, tool-supported method for conducting literature reviews in information systems. Paper presented at the 19th European conference on Information Systems, Helsinki, 221-233

Bitner, M.J. (1990). Evaluating service encounters: the effects of physical surroundings and employee responses. Journal of Marketing, 54(2), 69-82.

Bowen, J. (1990). Development of taxonomy of services to gain strategic marketing insights. Journal of the Academy of Marketing Science, 18, 43-49.

Brotheridge, C.M., \& Lee, R.T. (2002). Testing a conservation of resources model of the dynamics of emotional labor. Journal of Occupational Health Psychology, 7, 57-67.

Brotheridge, C.M., \& Lee, R.T. (2003). Development and validation of the emotional labor scale. Journal of Occupational and Organizational Psychology, 76, 365-379.

Chan, Y.Y., \& Ngai, E.W. (2011). Conceptualizing electronic word of mouth activity: an input process-output perspective. Marketing Intelligence \& Planning Journal, 29(5), 488-516.

Chi, N. W., \& Chen, P. C. (2018). Relationship matters: how relational factors moderate the effects of emotional labor on long-term customer outcomes. Journal of Business Research, (August 2018), 1-15.

Chu, K. H. L., \& Murrmann, S.K. (2006). Development and validation of the hospitality emotional labor scale. Tourism Management, 27, 1181-1191.

Diefendorff, J.M., Croyle, M.H., \& Gosserand, H. (2005). The dimensionality and antecedents of emotional labor strategies. Journal of Vocational Behavior, 66, 339-357.

Glomb, T.M., \& Tews, M.J. (2004). Emotional labor: a conceptualization and scale development. Journal of Vocational Behavior, 64, 1-23.

Goldberg, L. S., \& Grandey, A. A. (2007). Display rules versus display autonomy: emotion regulation, emotional exhaustion, and task performance in a call center simulation. Journal of Occupational Health Psychology, 12 , 301-318.

Grandey, A., Fisk, G., Mattila, A., Jansen, K.J.,\& Sideman, L. (2005). Is service with a smile enough? authenticity of positive displays during service encounters. Organizational Behavior \& Human Decision Processes, 96, 38-55.

Grandey, A.A. (2000). Emotion regulation in the workplace: a new way to conceptualize emotional labor. Journal of Occupational Health Psychology, 5(1), 95-110.

Gross, J. J. (1998a). Antecedent and response - focused emotion regulation: divergent consequences for experience, expression, and physiology. Journal of Personality and Social Psychology, 74(1), 224-237.

Gross, J. J. (1998b). The emerging field of emotion regulation: an integrative review. Review of General Psychology, 2, 271-299.

Groth, M., \& Hennig-thurau, T. (2009). Customer reactions to emotional labor: the roles of employee acting strategies and customer detection accuracy. Academy of Management Journal, 52(5), 958-974.

Groth, M., Hennig-Thurau, T., \& Walsh, G. (2009). Customer reactions to emotional labor: the roles of employee acting strategies and customer detection accuracy. Academy of Management Journal,52(5), 958-974.

Grove, S.J., Fisk, R.P., \& Dorsch, M.J. (1998). Assessing the theatrical components of the service encounter: a cluster analysis examination. Service Industries Journal, 18(3), 116-134.

Hochschild, A. (1979). Emotion work, feeling rules, and social structure. American Journal of Sociology, 85, 551575.

Hochschild, A.R. (1983). The Managed Heart: Commercialization of Human Feeling. Berkeley, University of California Press.

Huang, Y., Qu, H., \& Zhang, Y. (2011). Hotel frontline employee's emotional labor: the missing linkage between customer-related stress and burnout. International CHRIE Conference, Colorado, USA.

Hur, W.M., Moon, T.W. \& Jung, Y.S. (2015). Customer response to employee emotional labor: the structural 
relationship between emotional labor, job satisfaction, and customer satisfaction. Journal of Services Marketing, 29(1), 71-80.

Hwa, M.A., \& Amin, H. (2016). Why emotion at work matters: examining the influence of emotional labor and emotional intelligence on workplace behaviors among service workers in east Malaysia. Kajian Malaysia, 34(1), 79-105.

Jung, H.S.,\& Yoon, H.H. (2014). Antecedents and consequences of employees' job stress in a foodservice industry: focused on emotional labor and turnover intent. International Journal of Hospitality Management, 38, 84-88.

Jung, Y. S. (2015). Customer response to employee emotional labor: the structural relationship between emotional labor, job satisfaction, and customer satisfaction. Journal of Services Marketing, 29(1), 71-80.

Karim, J., \& Weisz, R. (2011). Emotional intelligence as a moderator of affectivity emotional labor and emotional labor/psychological distress relationships. Psychological Studies, 56(4), 348-359.

Khan, A., \& Awan, A. (2018). Customers responses to the emotional labor during service encounters. Journal of Marketing and Consumer Research,49, 38-50.

Kim, T., Yoo, J.J., Kim, J.,\& Lee, G. (2012).Emotional intelligence and emotional labor acting strategies among frontline hotel employees. International Journal of Contemporary Hospitality Management, 24(7), 10291046.

Kotler, P.,\& Keller, K.L. (2009). Marketing Management Pearson Education International (13 ${ }^{\text {rd }}$ Edition). NJ, Prentice Hall.

Lam, W. \& Chen, Z., 2012. When I put on my service mask: determinants and outcomes of emotional labor among hotel service providers according to affective event theory. International journal hospital management, 31(1), 3-11.

Lee, S. Y., Aziz, Y. A., Sidin, S. M. D., \& Saleh, R. (2014). The influence of emotional labor strategies on customer satisfaction and word of mouth recommendations in group tours. International Journal of Economics and Management, 8(Special issue), 81-96.

Lovelock, C., \& Wirtz, J. (2011). Services Marketing: People, Technology, Strategy. Upper Saddle River, New Jersey: Prentice Hall.

Medler-Liraz, H., \& Seger-Guttmann, T. (2015). The Relationship between emotional labor strategies, service provider hostility, and service quality. Services Marketing Quarterly, 36(3), 210-225.

Medler-Liraz, H., \& Yagil, D. (2013). Customer emotion regulation in the service interactions: its relationship to employee ingratiation, satisfaction and loyalty intentions. Journal of Social Psychology, 153(3), 261-278.

Mittal, V. \& Carly, F. (2010). Customer Satisfaction: A Strategic Review and Guidelines for Managers. Cambridge, MA: MSI Fast Forward Series, Marketing Science Institute.

Van Dijk, P. A., Liam, D. G., \& Smith, B. K. C. (2011). Are you for real? an evaluation of the relationship between emotional labor and visitor outcomes. Tourism Management journal, 32, 39-45.

Sharpe, K. (2005). Going above and beyond: the emotional labor of adventure guides. Journal of Leisure Research, 31(1), 29-35.

Tang, C., Naumann, S. E., \& Miguel, K. (2013). Emotional labor: the role of employee acting strategies on customer emotional experience and subsequent buying decisions. International Review of Management and Marketing, 3(2), 50-57.

Taylor, D.G., Strutton, D., \& Thompson, K. (2012). Self-Enhancement as a motivation for sharing online advertising. Journal of interactive marketing, 12(2), 28.

Van Dijk, P.A.,\& Kirk-Brown, A. (2007). Being somebody else: emotional labor and emotional dissonance in the context of the service experience at a heritage tourism site. Journal of Hospitality and Tourism Management, 14, 157-169.

Venkatesh, J., \& Balaj, J. (2013). The health care initiative for emotional for emotional labors. International Journal of Education and Research, 1(1), 1-9.

Wang, K. L. \& Groth, M. (2014). Buffering the negative effects of employee surface acting: the moderating role of employee-customer relationship strength and personalized services. Journal of Applied Psychology, 99(2), $341-350$.

Webster, J., \& Watson, R. (2002). Analyzing the past to prepare for the future: writing a literature review. MIS Quarterly, 26(2), 13-23.

Wong, J.Y., \& Wang, C.H. (2009). Emotional labor of the tour leaders: an exploratory study. Tourism Management, 30, 249-259.

Wu, C., \& Shen, C. (2013). Factors affecting customer positive emotion and service relation-restaurants in hotel as examples. International Journal of Business Tourism and Applied Science, 1(2), 30-41.

Wu, M. H., \& Yuan, Y. H. (2012). Research on the influence of emotional labor strategy used by public transportation employee on service satisfaction. International Journal of Social and Human Sciences, 6(2), 254-258.

Yagil, D. (2012). The mediating role of engagement and burnout in the relationship between employees' emotion 
regulation strategies and customer outcomes. European Journal of Work and Organizational Psychology, 21(1), 150-168.

Yuhanis, A.A. \& Zaiton, S. (2010). The impact of empowerment on emotional labor: a structural equation modeling approach. World Academy of Science, Engineering and Technology, 66, 1641-1653.

Zammuner, V.L., \& Galli, C. (2005). The Relationship with Patients: Emotional Labour and its Correlates in Hospital Employees. In Hartel, C.E.J., Zerbe, W.J. \& Ashkanasy, N.M. (Eds), Emotions in Organizational Behavior, Lawrence Erlbaum, Mahwah, NJ. 251-285.

Zapf, D. (2002). Emotion work and psychological well-being: a review of the literature and some conceptual considerations. Human Resource Management Review, 12, 237-268. 